\title{
Charles Bernstein
}

\section{FROM AN ONgOING INTERVIEW With TOM BeCKetT}

You say ironic I say comic, you say alienated

I say disaffected-besides I'm no alien, I'm from New York!

You've got to make the bridge before you can (double)

cross it. Give me a place to stand and I will look for

a place to sit. A poem should be at least as funny as

watching paint dry in the Cenozoic moonlight.

It's only a joke but then it's only a poem.

As Amberian has written:

In one-liners, there truth dwells in its [lowest] tracings

[lit. most base, close to the ground].

What was it Freud said about jokes, it slips my mind?

In the great historic project of undermining the hegemony of men's authoritative discourse, humor finds it hard

to keep a straight face. Is verse lite slighted?

Or is it one of those urban versus-

what do you call it now?-nonurban? issues,

in that much of the distrust of the comic extends a pastoral

and lyric tradition, a poetics of sincerity,

that the hyperironic (including the panironic, postironic,

malironic, cataironic, and paraironic), what you call radically ironic

poetry, actually

works to erode. But then, if you don't distrust the comic

what are you going to distrust? Just let me take off this

truss! To quote Amberian again

Sincerity is closest to deception

which no doubt echoes the well-known proverb,

"Beware a sincere man selling fish,"

which means, roughly, judge a man by what he says

not by his force of conviction or tone of veracity.

16 
Can we talk?

Sincerity is the last refuge of scoundrels, profundity an ingredient in every devil's potion, $\&$, hey, you!, don't tell me about love when you're turning your back on me as if to talk to some Higher Authority. The only Higher Authority I know about is my landlord and I already paid her this month. Against High Seriousness as such! I'm for a men's poetry that questions the importance of earnest anguish, of new-found sensitivity, of subjective acumen as market "tool," that wants to make fun of much that men hold dear. Surely there be that delight in giddiness, in which the ecstatic refuses to valorize itself. The raucous, the silly, the foolish render the viscosity of the world's vicissitudes. The shortest distance from transcendence to immanence is hilarity.

Let there be one, two, many languaging poetries! (There always have been.) Let readers coproduce meanings and let meanings coproduce readers! Let alienation be encountered so that alienation can be countered! Let counters be mixers and mixers be movers and movers put up big tents for lots of acts. And let disaffection melt away in the sounds of laughter so that grief may compose itself in the space between the laughs. 